\title{
Recyclability of Ore Beneficiation Wastes at the Lomonosov Deposit
}

\author{
Maria A. Pashkevich", Tatyana A. Petrova ${ }^{1}$ \\ 1 Saint Petersburg Mining University, 2, $21^{\text {st }}$ line V.O., St Petersburg, 199106, Russian Federation \\ * Corresponding author's e-mail: Pashkevich_MA@pers.spmi.ru
}

\begin{abstract}
The article presents the data based on the long-term observations of the Lomonosov mine tailing storage impact on the natural environment. The study of the chemical, mineral and phase composition of waste, sampled at the tailing site, was carried out. It was determined that the ore beneficiation waste in the Lomonosov deposit is generally represented by the minerals of the smectite group. According to the X-ray diffraction analysis data, the beneficiation wastes are a bi-mineral mixture of montmorillonite and talc with pyrophyllite impurities. The wastes of this composition are potentially magnesia raw materials used in the production of construction materials, such as cement, ceramic bricks, etc. Experimental studies have justified the use of the method of wastes recycling based on the roasting of the ore beneficiation tailings, with the number of process options, depending on the temperature regimes and the exposure time.
\end{abstract}

Keywords: waste storage, environmental hazard, wastes of diamond ore beneficiation, waste recycling

\section{INTRODUCTION}

In the areas of mining enterprises, one of the main sources of environmental disturbance and pollution is the ore processing solid waste storage. Up to now, the dominant method of ore waste storage is a land one. This storage method leads to the extreme environmental conditions within the territory of more than 4 million hectares, showing as a sanitary degradation, topography modification, as well as loss of natural resources.

The diamond ore beneficiation waste in the Lomonosov mine, stored in the tailings site produces an anthropogenic load on the natural environment. The beneficiation wastes are presented by high-yield clayey rocks, which leads to the increase in the tailings storage size and, consequently, enlargement of its impact zone. Annually, the mining processing plant of the Lomonosov deposit produces up to 3.3 million tons of ore and stores about 3 million tons of waste within the tailing site, which leads to an increase in the storage area and the height of its dam.

The anthropogenic impact of the tailings is magnified by the location of the Lomonosov mine in the Arkhangelsk Oblast (Russian Federation).
The northern ecosystems under the influence of the anthropogenic load are easily destroyed, since they have a low potential for self-purification and self-healing.

Technologically effective and environmentally sound solutions allowing diamond ore beneficiation wastes recycling have not been developed yet.

\section{MATERIALS AND METHODS}

The Lomonosov diamond mine is located in the Primorsky district of the Arkhangelsk region, $100 \mathrm{~km}$ north-east from the Arkhangelsk and is represented by six kimberlite pipes: Pomorskaya, Arkhangelskaya, Karpinsky-1, Karpinsky-2, Pionerskaya, and Lomonosov. Ore mining has been carried out since 2005 on the Arkhangelskaya pipe located in the southern part of the deposit. The Arkhangelskaya pipe is composed of tuffites, tuffaceous sandstones, breccias of sedimentary rocks, and sandstones. The kimberlite mineral composition is characterized by clay minerals pseudomorph after olivine. 
The concentrating plant and tailing facilities were put into operation in July 2005. The ore beneficiation includes wet type self-grinding of incoming ore, followed by separation into a granular material containing diamonds and the sludge entering the tailings pond. The diamond-bearing granular material is separated on high-frequency screens with the fine grading (less than $1.2 \mathrm{~mm}$ ) going to the tailings pond. A diamond-containing granular material of more than $1.2 \mathrm{~mm}$ in size is fed to X-ray luminescent separators, takes place after which hand picking. The waste rock is finally sent to the tailings pond.

The beneficiation waste is stored at the tailing pond, located $1.5 \mathrm{~km}$ north of the concentration plant, at a distance of $1 \mathrm{~km}$ from the Zolotitsa River. Hydraulic transport of tailings is carried out by means of a sludge pipe with a diameter of $325 \mathrm{~mm}$ and a length of $1800 \mathrm{~m}$.

Annually, more than 3 million $\mathrm{m}^{3}$ of tailings from the concentrating plant is fed to the tailings pond with a current total area of $4.8 \mathrm{~km}^{2}$. The eolian dust of the open beaches and tailings dam yields about 100 tons of inorganic dust with an amount of $\mathrm{SiO}_{2}$ from 70 to $20 \%$ per year, which leads to the formation of an atmochemical halo of an area of $16 \mathrm{~km}^{2}$. A significant proportion of dust in the atmospheric surface layer settles on the high-value forest landscapes [Conner \& Hoeffner, 1998; Pashkevich \& Petrova, 2017].

The unique characteristics of the Arkhangelsk region forest, which cannot be reproduced anywhere else in the world, are listed as follows:

- high strength of wood;

- attractive appearance;

- high strain resistance;

- resistance to dampness and temperature changes;

- resistance to decay, various pests and fungi;

- durability.
Reduction of the tailings dump impact on the forest landscapes can be achieved by at least partial utilization of the beneficiation waste [Alekseenko et al., 2017a; Kalb et al., 1991; Simpson, 1988]. The choice of the utilization method is largely determined by the waste composition [Pavolová et al., 2016; Rechard, 2000] In this regard, a complex of laboratory studies of waste, aimed at determining its chemical and mineral composition, as well as physical characteristics and mechanical properties, was carried out in the Center for Collective Use of the St. Petersburg Mining University. In 2016, the transported suspension and wastes stored in various areas of the tailing storage facilities were sampled for this purpose.

The content of rock-forming elements was determined for 4 averaged samples by means of XRF-1800 spectrometer, with a two repetitions for each measurement. The reference samples of clay and dunite were used to control data accuracy. The study showed that the composition of the beneficiation waste is equal to magnesian silicates. The results of the beneficiation waste chemical analysis are presented in Table 1.

The wastes mineral composition was determined with the x-ray powder diffraction, using XRD-7000 Shimadzu diffractometer. The phase identification was performed using the International Modified Reference Powder Diffraction File (PDF) and the database of American Society for Testing and Materials (ASTM).

The obtained XRD plots of the bulk samples are shown in Figure 1. The XRD plots for 4 samples showed no significant differences in their composition. The main mineral phases are quartz, montmorillonite, dolomite, calcite, hematite, K-feldspar, and probably a talc-pyrophyllite mineral, the precise determination of which is complicated because of its small content.

The granulometric analysis of the tailings was carried out using the Horiba LA-950 laser diffrac-

Table 1. Results of XRF spectroscopy of beneficiation wastes

\begin{tabular}{|c|c|c|c|c|c|c|c|c|c|c|}
\hline \multirow{2}{*}{ Sample } & \multicolumn{10}{|c|}{ Content, $\%$} \\
\hline & $\mathrm{iO}_{2}$ & $\mathrm{Al}_{2} \mathrm{O}_{3}$ & $\mathrm{MgO}$ & $\mathrm{Fe}_{2} \mathrm{O}_{3}$ & $\mathrm{CaO}$ & $\mathrm{K}_{2} \mathrm{O}$ & $\mathrm{TiO}_{2}$ & $\mathrm{MnO}$ & $\mathrm{Na}_{2} \mathrm{O}$ & $\mathrm{P}_{2} \mathrm{O}_{5}$ \\
\hline 1.1 & 46.86 & 6.44 & 23.78 & 5.05 & 4.12 & 0.86 & 0.55 & 0.072 & 0.37 & 0.31 \\
\hline 1.2 & 47.65 & 6.65 & 23.83 & 4.97 & 4.47 & 0.83 & 0.55 & 0.072 & 0.37 & 0.31 \\
\hline 2.1 & 45.24 & 6.75 & 24.63 & 5.08 & 3.6 & 0.81 & 0.63 & 0.074 & 0.59 & 0.30 \\
\hline 2.2 & 46.42 & 6.92 & 25.58 & 5.07 & 3.86 & 0.81 & 0.64 & 0.074 & 0.58 & 0.31 \\
\hline 3.1 & 46.14 & 6.09 & 24.03 & 5.4 & 4.0 & 0.83 & 0.53 & 0.068 & 0.37 & 0.31 \\
\hline 3.2 & 47.52 & 6.25 & 24.38 & 5.19 & 4.25 & 0.81 & 0.52 & 0.069 & 0.35 & 0.31 \\
\hline Susp-1 & 45.37 & 7.16 & 25.18 & 6.58 & 3.64 & 0.99 & 0.78 & 0.084 & 0.4 & 0.43 \\
\hline Susp -2 & 45.75 & 7.38 & 25.16 & 6.55 & 3.61 & 1.01 & 0.78 & 0.084 & 0.39 & 0.45 \\
\hline
\end{tabular}




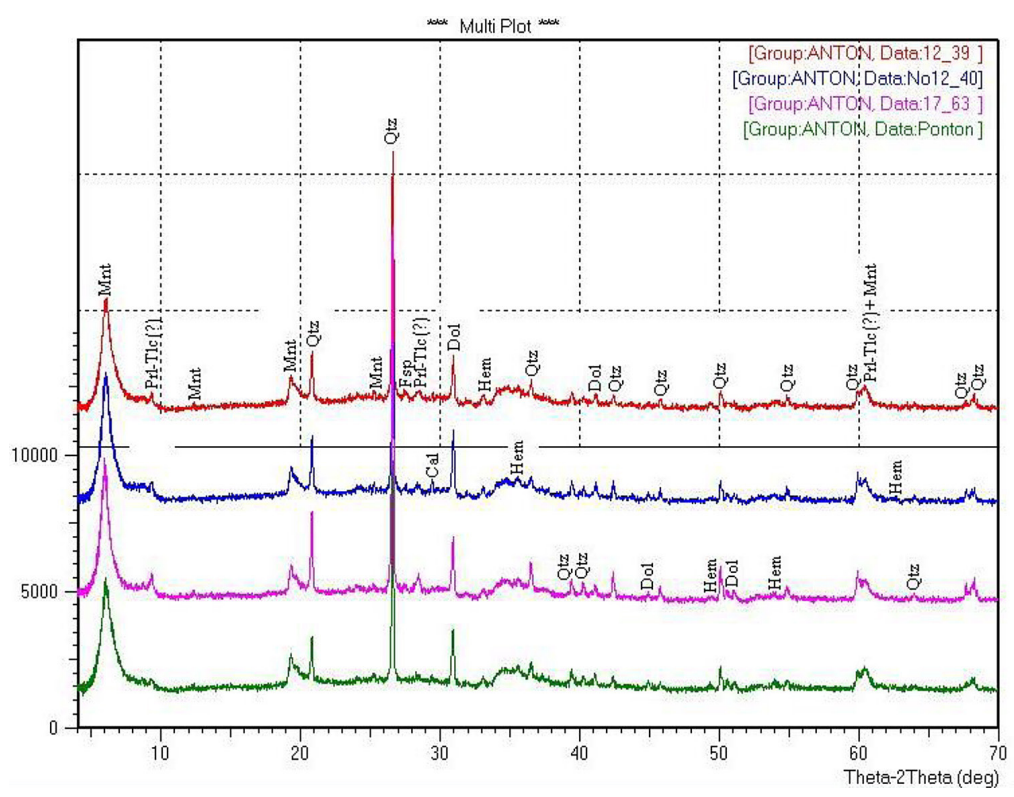

Fig. 1. XRD plots of the balk samples. Qtz - quartz, Mnt - montmorillonite, Dol - dolomite, Cal - calcite, Hem - hematite, Fsp - feldspar, Prl-Tlc - pyrophyllite-talc.

tion Particle Size Analyzer. The analytical results for the predominant particle size class of $-0.5 \mathrm{~mm}$ $(90 \%)$ are described below:

- less than $24.3 \mu \mathrm{m} \cong 85 \%$

- less than $10 \mu \mathrm{m} \cong 50 \%$

- less than $5 \mu \mathrm{m} \cong 30 \%$

The granulometric analysis allows ranging tails in the clay category. The water saturation of the rock was determined on a soil-swelling instrument [GOST 12248-2010; Jordán et al., 2016]. For the analysis correctness, the suspension samples were dehydrated and crushed in an agate mortar beforehand (Fig. 2).

The water saturation of the clayey suspension is much higher than that of the initial rock, which is explained by a change in the physical and chemical properties of the rock in the enrichment process. The plasticity index was determined for clay with the molding moisture content in accordance with GOST 21216-2014. The results of 10 measurements of the tailings are as follows: $\mathrm{Wt}$ $=44$ (yield point), $\mathrm{Wp}=30$ (the plasticity), and $\mathrm{P}=14$ (the plasticity index). Clay with plasticity index of 14 is moderately plastic.

\section{RESULTS}

The study of chemical and mineral composition, as well as physical characteristics and mechanical properties of diamond ore beneficiation wastes, showed the different ways of its utilization:
- for the production of construction materials (wall materials, ceramic bricks, cement clinker, etc.);

- in agriculture as a fertilizer for soil deoxidation [Alekseenko et al., 2017b], as a feed additive for animals, and as a natural agent for fodder conservation;

- as a drilling mud for oil wells drilling;

- as a natural absorbent, as a therapeutic mud, and as an element of the impermeable membrane on toxic waste storages [Glebov \& Lysenko, 1979; ÖzverdI \& Erdem, 2010; Peacock, 2000];

- as an ameliorant for waterlogged soils;

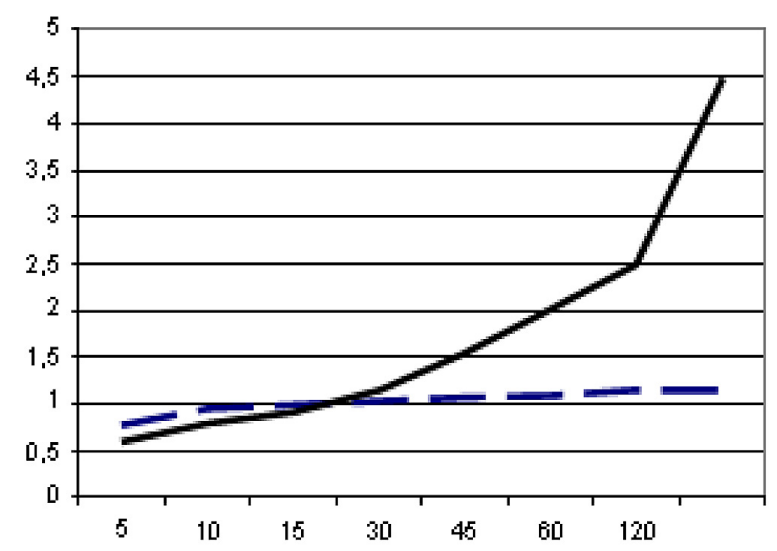

Fig. 2. Diagram comparing the water saturation of a clay suspension diamondiferous rock. The vertical axis is for swelling, $\mathrm{mm}$; the horizontal axis is for time, min; the dashed line is for the initial rocks; the continuous line is for the dehydrated suspension. 
- potential use as geogrids, with the intergrid space filled by dehydrated tails (the possibility of this utilization way is explained by the wastes high water absorption capacity) [Raj et al., 2005; Spence \& Shi, 2005; Tedder \& Pohland, 2002];

- in metallurgy as a raw material for the iron ore pellets and stone casting production [Beloglazov et al., 2014].

In connection with a significant amount of produced waste, the most promising strategy is the usage of wastes for the production of construction materials.

Since more than $67 \%$ of the wastes composition is represented by montmorillonite and saponite, which are magnesian clayey raw materials, the waste can be used in the production of such construction materials as ceramic bricks, ceramic and pressed wall materials, cement clinker, etc.

Considering the production of ceramic bricks, it should be said that an advanced semi-dry shaping is planned to be used as the sample preparation technique. The ceramic bricks production is promising for the region since the nearest largescale industry is located in Yaroslavl, from where the brick is imported to the Arkhangelsk region. The ceramic brick is a critical construction materialf the Arkhangelsk region. In total, there are 17 enterprises in the Northwestern Federal District that produce ceramic bricks (there are 100 plants in the Central Federal District and 128 in the Volga one) and there is a shortage of it, especially in the Arkhangelsk and neighbouring the Murmansk and Vologda regions. The main producers of ceramic bricks in the Northwestern Federal District are OJSC LSR Group, CJSC Etalon Building Materials Plant, and Keramik Service LLC, located in St. Petersburg and the Leningrad Region.

The term "wall materials" corresponds to ceramic and pressed wall panels. Wall panels can be produced from various types of mineral raw materials, for example, gypsum, asbestos, and clay. A promising method of recycling Lomonosov deposit wastes is their use as wall panels, both pressed and ceramic, with the addition of Portland cement, as a binder component of soft and moderately plastic clays $(\mathrm{Wt}=44)$.

Cement is always in demand in the construction industry, so its production is relevant, both for the needs of the enterprise itself and for the marketing. The cement clinker from the deposit can be used to produce cement at the Combine of Wall and Structural Materials in Arkhangelsk, and possibly, to supply the Savinsky Cement Plant, which is a part of the Eurocement group.

In order to determine whether the beneficiation wastes are suitable for the production of construction materials, tests for the tailing samples roasting were carried out. For this purposes, tailings were sampled from different depths $(3,3.5$, $4,4.5,5,5.5,6,6.5$, and $7 \mathrm{~m}$ ) of the drain well. The samples from different depth levels were finally averaged.

The disk samples of $32 \mathrm{~mm}$ in diameter and $32 \mathrm{~mm}$ in height were made from a clayey mass by a compression ring. The samples were roasted at different temperatures in the muffle furnace Polikon-613. The roasting process was divided into several stages:

1) Drying. It lasts for 10 hours at a temperature of $120^{\circ} \mathrm{C}$. During this time, water evaporates from the samples;

2) Dehydration. The temperature is $600^{\circ} \mathrm{C}$ for 5 hours. During this time, chemically bound water is removed from the samples;

$3)$ Roasting. Three roasting options were carried out at temperatures of 800,900 , and $1000^{\circ} \mathrm{C}$ for 4 hours;

4) Cooling down. Within 5 hours to a temperature of $50^{\circ} \mathrm{C}$.

There were 5 samples, produced by the roasting procedure at $800,900,1000^{\circ} \mathrm{C}$. The final ceramic samples were tested for uniaxial compression on a press with $\mathrm{F}_{\max }=500 \mathrm{kH}$. The obtained results are shown in Table 2 and in the Figure 3.

The experiments have shown that the optimum roasting temperature for increasing the brick strength is $900^{\circ} \mathrm{C}$ (Table 2). Roasting can be

Table 2. Uniaxial compression testing of samples

\begin{tabular}{|c|c|c|c|c|c|c|c|c|}
\hline $\begin{array}{c}\text { Set of the } \\
\text { samples }\end{array}$ & \multicolumn{2}{|c|}{$\begin{array}{c}\text { Roasting } \\
\text { temperature, }{ }^{\circ} \mathrm{C}\end{array}$} & \multicolumn{4}{c|}{$\begin{array}{c}\text { Mracture pressure, MPa } \\
\mathrm{MPa}\end{array}$} \\
\hline 1 & 120 & 2.00 & 2.36 & 2.11 & 2.24 & 2.27 & 2.19 & 2.63 \\
\hline 2 & 800 & 11.81 & 12.17 & 8.70 & 8.08 & 14.28 & 12.60 & 13.53 \\
\hline 3 & 900 & 12.44 & 13.18 & 16.02 & 9.95 & 9.95 & 13.01 & 14.91 \\
\hline 4 & 1000 & 8.08 & 9.70 & 8.83 & 11.44 & 10.07 & 9.62 & 11.54 \\
\hline
\end{tabular}




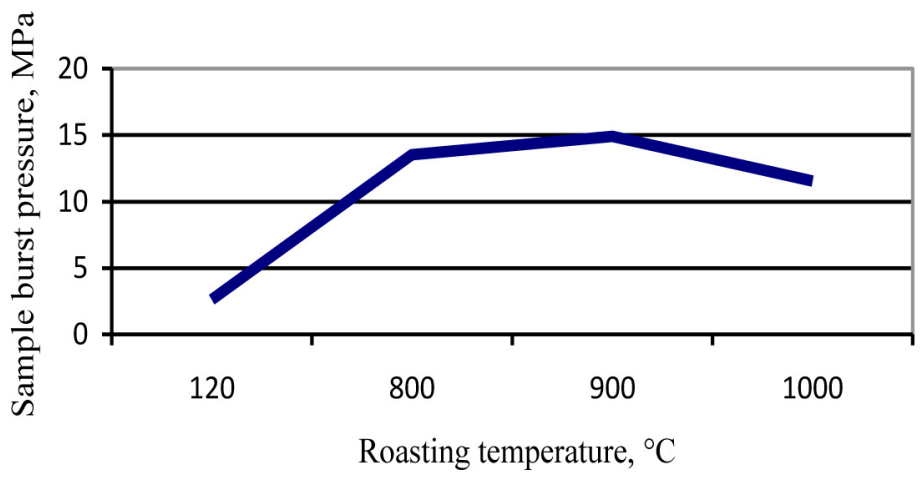

Figure 3. An empirical curve of the samples strength, MPa versus the roasting temperature

also carried out at a temperature of $800^{\circ} \mathrm{C}$ with a slight decrease in strength. A further temperature increase leads to an embrittlement (Fig. 3).

The experimental results confirmed the possibility of high-quality ceramic production from the beneficiation wastes. The use of tailings in the production of construction materials requires confirmation of its environmental safety. The samples of the solid mineral wastes and pulps were collected to assess its toxicity. Determination of the heavy metals bulk content in the samples of aqueous extract from solid mineral wastes was performed with the ICPE-9000 emission spectrometer after the samples grinding. Manual pulverization was carried out in an agate mortar. The samples were collected from various parts of the tailing beach, marked as 1, 2, and 3. Measurements were also performed for the dehydrated suspension. The results of the analysis are presented in Tables 3, 4 and 5.

The acidic extract for the ICP analysis was prepared with the use of hydrochloric acid, according to GOST 20432-83. After the required recalculations, the heavy metal content in the solid mineral waste and the tail suspensions were determined (Table 4).

The heavy metals contents do not exceed the standard indices [Cehlár et al., 2016; Greenwood \& Earnshaw, 1997; Pashkevich, 2017]. For ease of the results presentation, the contrast coefficients, defined as the ratio of the component concentration to the TLV, are given (table 5).

The contrast coefficients do not exceed 1 (table 5), which indicates that there are no excess concentrations of pollutants in the wastes. Then, the $5^{\text {th }}$ waste hazard class was calculated, and the

Table 3. Heavy metals concentrations in aqueous extracts from waste (mg/l)

\begin{tabular}{|c|c|c|c|c|c|c|}
\hline Sample & $\mathrm{Cd}, \mathrm{Co}$ & $\mathrm{Pb}$ & $\mathrm{Cu}$ & $\mathrm{Ni}$ & $\mathrm{Mn}$ & $\mathrm{Zn}$ \\
\hline 1 & $<0.0005$ & $<0.0010$ & 0.0040 & 0.0003 & 0.0023 & 0.0042 \\
\hline 2 & $<0.0005$ & $<0.0010$ & 0.0040 & 0.0003 & 0.0022 & 0.0065 \\
\hline 3 & $<0.0005$ & $<0.0010$ & 0.0026 & 0.0007 & 0.0015 & 0.0024 \\
\hline Suspended matter & $<0.0005$ & $<0.0010$ & 0.0036 & 0.0006 & 0.0021 & 0.0010 \\
\hline
\end{tabular}

Table 4. Results of solid mineral waste and clayey suspension samples analysis

\begin{tabular}{|c|c|c|c|c|c|c|c|c|}
\hline \multirow{2}{*}{ Sample } & \multicolumn{9}{|c|}{ Element content, ppm } \\
\cline { 2 - 9 } & $\mathrm{Cd}$ & $\mathrm{Co}$ & $\mathrm{Cr}$ & $\mathrm{Cu}$ & $\mathrm{Ni}$ & $\mathrm{Pb}$ & $\mathrm{Sr}$ & $\mathrm{Zn}$ \\
\hline 1.1 & 0.5 & 13 & 134 & 2.5 & 214 & 10 & 22 & 20 \\
\hline 1.2 & 0.6 & 13 & 141 & 2.7 & 227 & 10 & 20 & 21 \\
\hline 2.1 & 0.6 & 15 & 157 & 2.6 & 245 & $<1.0$ & 20 & 23 \\
\hline 2.2 & 0.5 & 12 & 138 & 2.5 & 206 & $<1.0$ & 21 & 19 \\
\hline 3.1 & 0.5 & 11 & 123 & 2.4 & 208 & $<1.0$ & 21 & 17 \\
\hline 3.2 & 0.7 & 12 & 132 & 2.6 & 216 & $<1.0$ & 21 & 20 \\
\hline Susp-1 & 0.5 & 13 & 136 & 2.7 & 196 & $<1.0$ & 21 & 18 \\
\hline Susp-2 & 0.8 & 14 & 163 & 2.3 & 207 & $<1.0$ & 42 & 23 \\
\hline
\end{tabular}


Table 5. Contrast coefficient (component concentration to the TLV ratio)

\begin{tabular}{|c|c|c|c|c|c|c|c|c|}
\hline \multirow{2}{*}{ Sample } & \multicolumn{8}{|c|}{ Contrast coefficient } \\
\hline & $\mathrm{Cd}$ & Co & $\mathrm{Cr}$ & $\mathrm{Cu}$ & $\mathrm{Ni}$ & $\mathrm{Pb}$ & $\mathrm{Sr}$ & $\mathrm{Zn}$ \\
\hline 1.1 & 0.25 & 0.26 & 0.21 & 0.83 & 0.52 & 0.32 & 0.27 & 0.86 \\
\hline 1.2 & 0.3 & 0.26 & 0.23 & 0.9 & 0.55 & 0.32 & 0.25 & 0.91 \\
\hline 2.1 & 0.3 & 0.3 & 0.25 & 0.86 & 0.60 & $<0.03$ & 0.25 & 1.0 \\
\hline 2.2 & 0.25 & 1.2 & 0.21 & 0.83 & 0.50 & $<0.03$ & 0.26 & 0.82 \\
\hline 3.1 & 0.25 & 0.24 & 0.20 & 0.80 & 0.50 & $<0.03$ & 0.26 & 0.73 \\
\hline 3.2 & 0.35 & 0.24 & 0.21 & 0.86 & 0.52 & $<0.03$ & 0.26 & 0.86 \\
\hline Susp-1 & 0.25 & 0.26 & 0.21 & 0.9 & 0.47 & $<0.03$ & 0.26 & 0.78 \\
\hline Susp-2 & 0.20 & 0.28 & 0.26 & 0.76 & 0.5 & $<0.03$ & 0.52 & 0.95 \\
\hline
\end{tabular}

waste was determined as inert. Thus, the products obtained from the diamond ore beneficiation waste of the Lomonosov deposit have no impact on health and meets sanitary standards.

\section{CONCLUSIONS}

1. Long-term field studies in the impact zone of the diamond ore beneficiation waste storage of the Lomonosov deposit showed that the construction and operation of the tailing dump negatively affects the large areas of $4.8 \mathrm{~km}^{2}$. Moreover, the dry tailing beaches dusting leads to the formation of atmospheric pollution halos with an area of $16 \mathrm{~km}^{2}$;

2. Study on the chemical, mineral and phase composition of wastes allowed to determine if it can be used in different ways of recycling;

3. Experimental studies enabled to determine the temperature conditions of tailings roasting for the construction materials production;

4. It was resolved that the products obtained from the diamond ore beneficiation wastes of the Lomonosov deposit have no impact on health and meet sanitary standards.

\section{Acknowledgments}

The analyses were performed using the equipment of the Common Use Centre of Saint Petersburg Mining University.

\section{REFERENCES}

1. Alekseenko, V.A., Maximovich, N.G., Alekseenko, A.V., 2017a. Geochemical Barriers for Soil Protection in Mining Areas. In: Bech, J., Bini, C., Pashkevich, M.A. (eds.) Assessment, Restoration and Reclamation of Mining Influenced Soils, Elsevier Inc.
DOI: 10.1016/B978-0-12-809588-1.00009-8

2. Alekseenko, V.A., Shvydkaya, N.V., Alekseenko, A.V., Yashchinin, S.B., 2017b. Natural Restoration of Mining Influenced Soils in the Northwestern Caucasus, Russia. In: Bech, J., Bini, C., Pashkevich, M.A. (eds.) Assessment, Restoration and Reclamation of Mining Influenced Soils, Elsevier Inc. DOI: 10.1016/B978-0-12-809588-1.00010-4

3. Beloglazov, I.I., Suslov, A.P. Pedro, A.A., 2014. Change of constant component of phase voltage during melting of zirconium corundum. Tsvetnye Metally, 5, pp. 86-89.

4. Cehlár, M., Domaracká, L., Šimko, I., Puzder, M., 2016. Mineral resource extraction and its political risks. Production Management and Engineering Sciences - Scientific Publication of the International Conference on Engineering Science and Production Management, ESPM 2015, pp. 39-43.

5. Conner, J.R., Hoeffner, S.L., 1998. A Critical Review of Stabilization/Solidification Technology. Critical Reviews in Environmental Science and Technology, 28 (4), pp.397-462.

6. Glebov, V.D., Lysenko, V.P., 1979. Calculation of the thickness of the polymer film impervious screens. Hydraulic engineering construction, 6, pp. 17-20.

7. GOST 12248-2010. Soils. Laboratory methods for determining the strength and strain characteristics

8. GOST 20432-83. Fertilizers. Terms and definitions

9. GOST 21216-2014. Clay raw materials. Test methods

10. Greenwood, N.N., Earnshaw, A., 1997. Chemistry of the Elements. 2nd Edition. Butterworth-Heinemann.

11. Jordán M.M., Bech J., García-Sánchez E., GarcíaOrenes F., 2016. Bulk density and aggregate stability assays in percolation columns. Journal of Mining Institute. Vol. 222, pp. 877-881.

12. Kalb, P.D., Heiser, J.H., Colombo, P., 1991. Longterm durability of polyethylene for encapsulation of low-level radioactive, hazardous, and mixed wastes.

13. ÖzverdI, A., Erdem, M., 2010. Environmental risk assessment and stabilization/solidification of zinc 
extraction residue: I. Environmental risk assessment. Hydrometallurgy, 100 (3-4), pp.103-109.

14. Pashkevich, M.A., 2017. Classification and Environmental Impact of Mine Dumps. In: Bech, J., Bini, C., Pashkevich, M.A. (eds.) Assessment, Restoration and Reclamation of Mining Influenced Soils, Elsevier Inc. DOI: 10.1016/ B978-0-12-809588-1.00001-3

15. Pashkevich, M.A., Petrova, T.A., 2017. Reclamation by Containment: Polyethylene-Based Solidification. In: Bech, J., Bini, C., Pashkevich, M.A. (eds.) Assessment, Restoration and Reclamation of Mining Influenced Soils, Elsevier Inc. DOI: 10.1016/B978-0-12-809588-1.00008-6

16. Pavolová, H., Khouri, S., Cehlár, M., Domaracká, L., Puzder, M., 2016. Modelling of copper and zinc adsorption onto zeolite. Metalurgija, 55 (4), pp. 712-714.

17. Peacock, A., 2000. Handbook of Polyethylene:
Structures: Properties, and Applications, CRC Press.

18. Raj, D.S.S. et al., 2005. Stabilisation and solidification technologies for the remediation of contaminated soils and sediments: an overview. Land Contamination, Reclamation, 13 (1), pp.23-48.

19. Rechard, R.P., 2000. Historical background on performance assessment for the Waste Isolation Pilot Plant. Reliability Engineering, System Safety, 69 (1-3), pp. 5-46.

20. Simpson, H.E., 1988. Artificial deposits and modified land. In: Encyclopedia of Earth Sciences. General Geology. Springer US.

21. Spence, R.D., Shi, C., 2005. Stabilization and Solidification of Hazardous, Radioactive, and Mixed Wastes, Taylor, Francis.

22. Tedder, D.W., Pohland, F.G. eds., 2002. Emerging Technologies in Hazardous Waste Management 8, Boston: Kluwer Academic Publishers. 